\title{
Retraction Note to: Analyses of Economic Development Based on Different Factors
}

\author{
Goran Maksimović ${ }^{1} \cdot$ Srdan Jović ${ }^{2}$. \\ David Jovović ${ }^{1}$ - Marina Jovović ${ }^{3}$
}

Published online: 16 November 2019

(c) Springer Science+Business Media, LLC, part of Springer Nature 2019

\section{Retraction Note to: Comput Econ (2019) 53:1103-1109 https://doi.org/10.1007/s10614-017-9786-1}

The Editor-in-Chief has retracted this article (Maksimović et al. 2019) because validity of the content of this article cannot be verified. This article showed evidence of substantial text overlap [most notably with the articles cited Mladenovic et al. (2016), Gocić et al. (2015), Pourtahmasb et al. (2015), Pourtousi et al. (2015)] and authorship manipulation. None of the authors agree with the retraction.

\section{References}

Gocić, M., Motamedi, S., Shamshirband, S., et al. (2015). Potential of adaptive neuro-fuzzy inference system for evaluation of drought indices. Stochastic Environmental Research and Risk Assessment, 29, 1993-2002. https://doi.org/10.1007/s00477-015-1056-y.

Maksimović, G., Jović, S., Jovović, D., et al. (2019). Analyses of economic development based on different factors. Computational Economics, 53, 1103-1109. https://doi.org/10.1007/s10614-017-9786-1.

Mladenovic, I., Milovancevic, M., Mladenovic, S., et al. (2016). Analyzing and management of health care expenditure and gross domestic product (GDP) growth rate by adaptive neuro-fuzzy technique. Computers in Human Behavior, 64, 524-530. https://doi.org/10.1016/j.chb.2016.07.052.

Pourtahmasb, M., Karim, M., \& Shamshirband, S. (2015). Resilient modulus prediction of asphalt mixtures containing recycled concrete aggregate using an adaptive neuro-fuzzy methodology. Construction and Building Materials, 82, 257-263. https://doi.org/10.1016/j.conbuildmat.2015.02.030.

Pourtousi, M., Sahu, J., \& Ganesan, P. (2015). A combination of computational fluid dynamics (CFD) and adaptive neuro-fuzzy system (ANFIS) for prediction of the bubble column hydrodynamics. Powder Technology, 274, 466-481. https://doi.org/10.1016/j.powtec.2015.01.038.

Publisher's Note Springer Nature remains neutral with regard to jurisdictional claims in published maps and institutional affiliations.

Srđan Jović

srdjanjovic2016@hotmail.com

1 University of Priština, Faculty of Agriculture, Kopaonička, Lešak 38219, Serbia

2 University of Priština, Faculty of Technical Sciences, Kneza Milosa 7,

Kosovska Mitrovica 38220, Serbia

3 Business School of Applied Studies in Blace, Kralja Petra I 70, Blace 18420, Serbia 